Journal

of Geography

Politics and Society

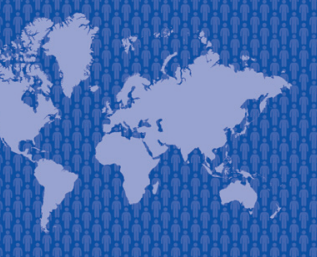

$8(1) / 2018$

\section{Journal of Geography, Politics and Society}

$2018,8(1), 44-48$

DOI 10.4467/24512249JG.18.005.8157

\title{
ENSURING EQUAL REGIONAL EMPLOYMENT CONDITIONS AS A MECHANISM TO OVERCOME THE PROBLEMS OF EMPLOYMENT OF INTERNALLY DISPLACED PERSONS
}

\author{
Viktoriia Semenenko \\ Department for Human Development Studies, Ptoukha Institute for Demography and Social Studies of the National Academy of Sciences of Ukraine, Taras \\ Shevchenko Boulevard 60, 01032 Kyiv, Ukraine, \\ e-mail: vika_vz@ukr.net
}

\section{Citation}

Semenenko V., 2018, Ensuring equal regional employment conditions as a mechanism to overcome the problems of employment of IDPs, Journal of Geography, Politics and Society, 8(1), 44-48.

\begin{abstract}
The scale of interregional inequality of employment conditions for internally displaced persons (IDP), in particular, according to the basic indicators of the block «Decent work» of the index of regional human development is determined. The manifestations of the irregularity of placement of internally displaced persons in the regional cut are analyzed. This problem complicates the implementation of the employment policy concerning IDP's needs. The experience of solving the IDP's problems connected with their irregular placement, their employment, the balancing of the labor market on the basis of equalization of the dynamic equilibrium of interregional conditions of access to stable employment is generalized. The recommendations for the equalization of interregional conditions of IDP's employment, which are necessary for deepening of the social dialogue in the field of labor relations, are substantiated.
\end{abstract}

\section{Key words}

equalization, internally displaced persons, stable employment, unemployment, Ukraine.

\section{Introduction}

One of the most serious social and economic problems in Ukraine as a result of Russian aggression, the annexation of Crimea and the actual occupation of certain areas of Donbas is the forced displacement of many Ukrainians from places of residence to other regions of Ukraine and the front zone of Donetsk and Luhansk oblasts. Forcibly displaced persons left their homes, lost their property, severed social ties. As a result, in their new places of residence they became less competitive than locals, as well as themselves in their pre-war life (Муромцева, 2015; Тищенко, Піроцький, 2014; Малиха, 2015; Коваліско, Бубняк, 2016). The employment situation in the regionsmain recipients of internally displaced persons (IDP) $s$ impedes the solution of the problem of their employment. Even before 2014, the situation in such regions was characterized by significant interregional inequality of employment conditions, in particular, 


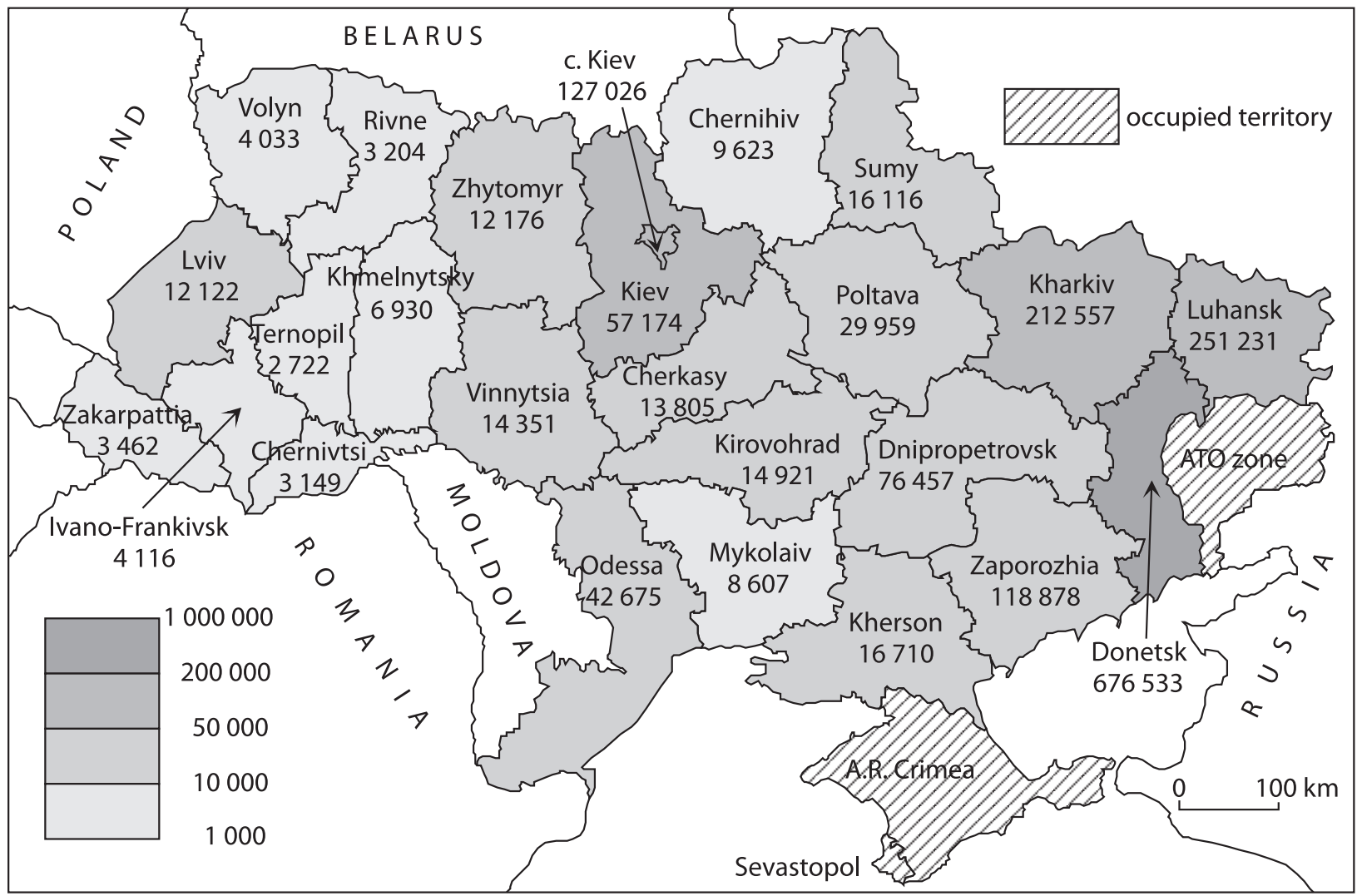

Fig. 1. Distribution of internally displaced persons from the occupied Donbas and Crimea by regions of Ukraine in 2017 Source: http://www.msp.gov.ua/en/

in terms of employment level, unemployment, the share of employees receiving a salary of less than 1.5 subsistence minimums, the share of workers working in conditions that do not meet sanitary and hygiene standards, the ratio of average wages to the minimum, the level of social insurance coverage, etc. (Бубняк, 2016; Дерев'янко, 2017). In these conditions, it is not enough to use traditional instruments of state support for noncompetitive categories of the population at the labour market (Лібанова et al., 2015).

The solution of the problem requires the formation of a comprehensive macro-regional policy of ensuring equal territorial employment conditions.

\section{Research results analysis}

According to the Ministry of Social Policy in the third quarter of 2017, 1596644 internally displaced persons were registered (Обліковано..., 2017). The largest number of internally displaced persons is registered in Donetsk (676 533 persons), Luhansk (251 231 persons), Kharkiv (212 557 persons), Kyiv (127 026 persons), Zaporizhzhia (118 878 persons), Dnipropetrovsk (76 457 persons) oblasts. The smallest number of IDPs was settled in Ternopil
(2 722 persons), Chernivtsi (3 149 persons), Rivne (3 204 persons), Zakarpattia (3 462 persons), IvanoFrankivsk (4 116 persons) and Volyn (4 033 persons) oblasts (Fig. 1). This demonstrates the unequal regional allocation of IDPs in Ukraine, which leads to the excessive social and administrative burden on local labour markets, social infrastructure of the regions of the occupation. The unequal distribution of internally displaced persons across the regions complicates the employment policy implementation.

The concentration of IDPs in several oblasts (Donetsk, Luhansk, Kharkiv, Zaporizhzhia and Dnipropetrovsk) further complicates the problem of inequality of regional employment conditions, which was quite urgent before the aggression of the Russian Federation.

For example, in 2013 the difference between the regions with high employment rates ${ }^{1}$ and the smallest reached 7-8 p.p. with an average of $65.5 \%$ in Ukraine, and by the unemployment rate the

\footnotetext{
1 The areas with a relatively high level of any index of the labour market of Regional Human Development Index include those whose level exceeds the average regional value of the investigated indicator for more than one standard deviation. Accordingly, areas with relatively low values include those whose level is lower than the average regional value of the investigated indicator more than one standard deviation
} 
difference was $3-4$ p.p. ( $7.25 \%$ in the country as a whole), by the share of workers receiving a salary of less than 1.5 subsistence minimums - 12-16 p.p. ( $30.7 \%$ in the country as a whole), by the share of workers working in conditions that do not meet sanitary and hygienic standards $-31-38$ p.p. $(29.5 \%$ in the country as a whole), by the indicator of the ratio of average wages to the minimum - in 0.9-1.1 times ( 2.7 times in the country as a whole), by social insurance coverage level $-25-30$ p.p. $(67.1 \%$ in the country as a whole) (Методика..., 2012).

By the same indicators, Dnipropetrovsk, Zaporizhzhia and Kharkiv oblasts belonged to a group of high employment, low and average unemployment level, while Donetsk and Luhansk, on the contrary, were characterized by a relatively low level of employment and a high level of unemployment. At the beginning of 2017 these indicators worsened, and the difference between successful and backward regions became greater. Thus, even a brief review of the Decent Work indicators of the Regional Human Development Index showed strong regional asymmetries in the economic potential of territories, the differentiation of the population in terms of the availability of material and spiritual goods, the heterogeneity of opportunities for decent working conditions (Лібанова et al., 2016).

In these conditions, access to employment and employment for IDPs remains worse than for local people, and in general the inequality in the region deepens. In particular, in Poltava oblast the share of managers and specialists among the unemployed IDPs is $48.3 \%$, while among local unemployed is $27.8 \%$. If the majority of the unemployed IDPs are persons aged $30-45$, then among the locals it is mostly young people. In terms of education, $57.1 \%$ of the unemployed IDPs have higher education, and the share of the unemployed persons with higher education among the so-called 'native persons' is $40.1 \%$. The unemployed IDPs are mostly represented by females. If among all registered the unemployed in all categories, the share of women was $55 \%$, then among the unemployed IDPs $-65 \%$ and it ranged from $56 \%$ in Chernivtsi oblast to $78 \%$ in Volyn oblast (Інтегральний індекс..., 2013; Методика..., 2013; Цимбал, 2009).

The state realizes that IDPs' problems are drastic, but it pays little attention to interregional imbalances in employment conditions. This leads to the fact that much has been done to help IDPs, but all the measures have proved to be point-blank and not systematically related to the processes of formation of regional employment conditions and interregional imbalances. Thus, in accordance with Article 24-1 of the Law of Ukraine 'On Employment of the
Population' (Про зайнятість ..., 2012), the following measures are provided for the promotion of employment of internally displaced persons:

- compensation of labour costs for the employed unemployed internally displaced persons to employers;

- compensation of expenses for their retraining or advanced training;

- compensation of actual expenses for moving to another administrative-territorial unit of the employment place and expenses for passing medical examination, if it is necessary for employment. However, these legislative improvements have not been effective in practice. From March 1, 2014 till the first quarter of 2017, the State Employment Service promoted the employment of 25.6 thousand internally displaced persons, which is apparently insufficient for the contingent of IDPs, which ranged from 1 to 1.8 million at different times (Ринок праці..., 2016).

According to the State Employment Service, as of August 1, 2017, 5.2 thousand people who received a certificate of registration as persons moving from temporarily occupied territory of Ukraine or areas of ATO continued to receive services of the State Employment Service, 3.9 thousands of which had the status of the unemployed (Ринок праці ..., 2016).

Therefore, at present, a problem of balancing the labour market based on the support of the dynamic balance of interregional conditions is rather urgent. It is reasonable to proceed from the assumption that most of IDPs will remain permanently on their new places of residence and the relevant state policy should be based on the creation of conditions for their residence (Калачова (eds.), 2013).

Priorities for developing mechanisms for ensuring equal interregional employment conditions should be stimulation of demand for labour through creating new enterprises and introducing new types of economic activity. This does not mean the inappropriateness of creating jobs at already operating enterprises, but it should be accompanied by creation of new enterprises, processes of demonopolization, search for new forms of their reintegration and cooperation. At the same time, main preference should be given to creating conditions for innovative development and fundamental change in the demography of the entrepreneurial landscape. And not only industrial complexes, but also sectors of infrastructure development, construction, agriculture complex, public administration and social sphere have a potential for that.

The next step should be a focus on the creation of high-quality jobs, diversified jobs and jobs of "start-to-finish" specialization and qualifications. The 
organizational and technological policy of enterprises should provide the demand for skilled workers, operators and service engineers in installation of complex technical systems, specialists of engineering and technical staff, and professional managers.

The state should stimulate a policy of abandoning cheap labour, which is especially important for enterprises-locomotives of innovation in the industrial, construction and infrastructure sectors (Ринок праці..., 2016).

\section{Summary}

It is important to create jobs in small and micro-enterprises to stimulate a creative self-realization of the population; to develop the environment of start-ups and venture companies; to create small and microenterprises that will support large enterprises (within the framework of gravity integration systems), outsourcing and/or competitive contractors of the common production chain, innovation manufacturing networks, service and logistics networks within the territorial clusters.

The next step should be overcoming territorial and sectoral imbalances and developing infrastructure and institutions for active labour mediation and consulting (both private and public). It is necessary to create a system of information mediation and consulting on issues of employment with a fundamentally different level of activity. A powerful consulting company should work, which will be capable of expeditiously, targetedly and comprehensively explaining the value of available information, providing professional orientation, adaptation and deactivation services.

To activate social partnership in the complex ensuring equal employment interregional conditions and employment of IDPs, it is necessary to deepen a social dialogue in the field of labour relations, forecast employment in all spectra of relevant parameters, to create a modern system of professional qualification and attestation, professional skilled and professional and educational coordination. This process should not be limited to the traditional circle of "authorities-employer-trade union" participants. Any organized forms of collective interest: from labour collectives to territorial communities and public organizations have to be involved.

The next step should be support of flexible and non-traditional forms of employment. This will make it possible to formulate approaches to the temporary solution of the problems of mass unemployment of the labour force of low qualification and out-of-date occupations, temporary and part-time employment, informal employment, as well as irregular self-employment, etc.

\section{References}

http://www.msp.gov.ua/en/, Ministry of Social Policy of Ukraine. Official Web-Site.

Бубняк С., 2016, Внутрішньо переміщені особи в Україні на прикладі м. Львова, Грані, 140, 16-21.

Дерев'янко С., 2017, Внутрішньо переміщені особи: проблеми політичної соціалізації в Галичині, Наукові записки Інституту політичних і етноначіональних досліджень ім. І. Ф. Кураса НАН України, 1, 199-216.

Інтегральний індекс регіонального людського розвитку за 2013 р., 2013, Моніторинг Інституту демографії та соціальних досліджень ім. М. В. Птухи НАН України, http:// www.idss.org.ua/ukr_index.html [06.10.2017].

Калачова I.B. (eds.), 2013, Регіональний людський розвиток. Статистичний бюлетень, Державний комітет статистики України, Київ, http://ukrstat.org/uk/metod_polog/ menu/07_posl.htm [06.10.2017].

Коваліско Н., Бубняк С., 2016, Внутрішньо переміщені особи в Україні: моніторинг результатів соціологічних досліджень 2014-2015, Вісник Одеського національного університету. Соціологія і політичні науки, 1, 38-46.

Лібанова Е., Горбулін В., Пирожков С., 2015, Політика інтеграції українського суспільства в контексті викликів та загроз подій на Донбасі (національна доповідь), Національна Академія Наук України, Київ.

Лібанова Е., Цимбал О., Ярош О., Лісогор Л., 2016, Перехід на ринок праці молоді України:результати міжнародного дослідження «School-to-work transition surveys» в Україні у 2013 та 2015 роках, Міжнародне бюро праці, Женева, http://www.ilo.org/wcmsp5/groups/public/---ed_emp/ documents/publication/wcms_536293.pdf [06.10.2017].

Малиха M.І., 2015, До проблеми сутності поняття «внутрішньо переміщені особи»: державна політика та регіональна практика, Грані, 8, 6-11.

Методика вимірювання регіонального людського розвитку, 2012, Міністерство економічного розвитку й торгівлі України. Державна служба статистики. Інститут демографії та соціальних досліджень ім. М.В. Птухи НАН України, Київ, http://www.idss.org.ua/public.html\# [06.10.2017]

Методика вимірювання регіонального людського розвитку, 2013, [in:] І.В. Калачова (eds.), Регіональний людський розвиток. Статистичний бюлетень, Державний комітет статистики України, Київ, 9-36, http://ukrstat.org/uk/metod_polog/menu/07_posl.htm [06.10.2017].

Муромцева Ю.І., 2015, Внутрішньо переміщені особи в Україні та їх вплив на ринок праці регіону, [in:] 3бірник наукових праць Харківського начіонального педагогічного університету імені Г. С. Сковороди. Економіка, 15, 124-131.

Обліковано 1596644 переселенці, - Мінсоцполітики, 2017, Міністерство соціальної політики України, 2017, http:// www.msp.gov.ua/news/14003.html [06.10.2017]. 
Про зайнятість населення. Закон України від 05.07.2012 p. № 5067-VI, 2012, Відомості Верховної Ради України, http://zakon2.rada.gov.ua/laws/show/5067-17/page [06.10.2017].

Ринок праці у I півріччі 2016 року, 2016, Державна служба статистики України, Київ.

Тищенко Н.І., Піроцький Б.Ю., 2014, Внутрішньо переміщені особи в Україні як проблема сьогодення, Молодий вчений, 10(13/2), 124-126.

Цимбал О.І., 2009, Регулювання збалансованого розвитку формальних та імпліцитних структур інституалізації відтворювального простору ринку праці, Зайнятість таринок прачі, 21/22, 25-40. 